\title{
MicroRNA519d and microRNA4758 can identify gangliogliomas from dysembryoplastic neuroepithelial tumours and astrocytomas
}

\author{
Anika Bongaarts ${ }^{1, *}$, Avanita S. Prabowo ${ }^{1, *}$, Andrea Arena ${ }^{1,2}$, Jasper J. Anink ${ }^{1}$, Roy J. \\ Reinten ${ }^{1}$, Floor E. Jansen ${ }^{3}$, Wim G.M. Spliet ${ }^{4}$, Maria Thom ${ }^{5}$, Roland Coras ${ }^{6}$, Ingmar \\ Blümcke $^{6}$, Katarzyna Kotulska7, Sergiusz Jozwiak ${ }^{7,8}$, Wieslawa Grajkowska ${ }^{9}$, \\ Figen Söylemezoğlu ${ }^{10}$, José Pimentel ${ }^{11}$, Antoinette Y.N. Schouten-van Meeteren ${ }^{12}$, \\ James D. Mills ${ }^{1}$, Anand M. Iyer ${ }^{1}$, Erwin A. van Vliet ${ }^{1}$, Angelika Mühlebner ${ }^{1,13}$ and \\ Eleonora Aronica ${ }^{1,14}$

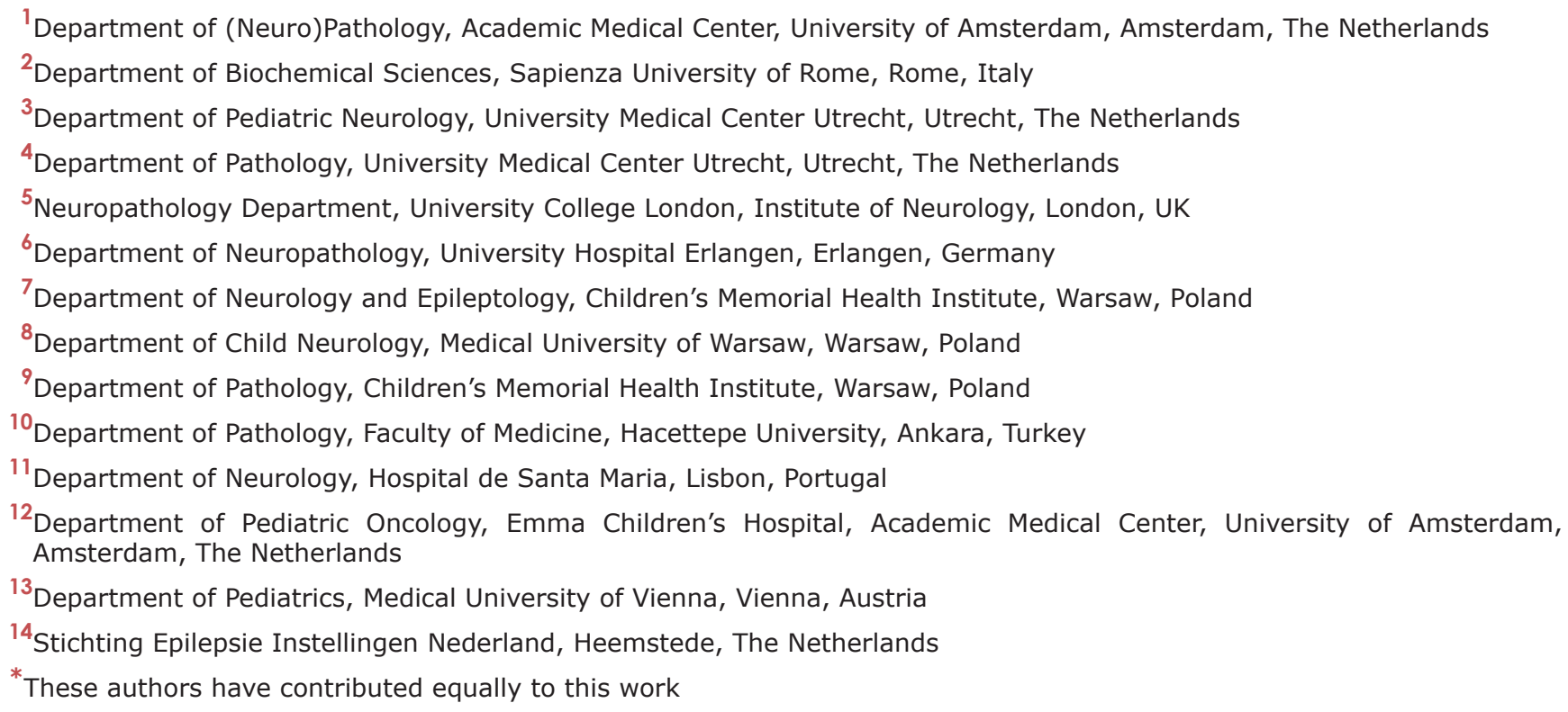

Correspondence to: Eleonora Aronica, email: e.aronica@amc.uva.nl

Keywords: low-grade epilepsy-associated brain tumours, epilepsy, glioneuronal tumour, ganglioglioma, dysembryoplastic neuroepithelial tumour

Received: March 14, $2018 \quad$ Accepted: May 19, $2018 \quad$ Published: June 15, 2018

Copyright: Bongaarts et al. This is an open-access article distributed under the terms of the Creative Commons Attribution License 3.0 (CC BY 3.0), which permits unrestricted use, distribution, and reproduction in any medium, provided the original author and source are credited.

\section{ABSTRACT}

Glioneuronal tumours, including gangliogliomas and dysembryoplastic neuroepithelial tumours, represent the most common low-grade epilepsy-associated brain tumours and are a well-recognized cause of intractable focal epilepsy in children and young adults. Classification is predominantly based on histological features, which is difficult due to the broad histological spectrum of these tumours. The aim of the present study was to find molecular markers that can be used to identify entities within the histopathology spectrum of glioneuronal tumours. The focus of this study was on microRNAs (miRNAs). miRNAs are important post-transcriptional regulators of gene expression and are involved in the pathogenesis of different neurological diseases and oncogenesis. Using a miRNA array, miR-519d and miR4758 were found to be upregulated in gangliogliomas $(n=26)$ compared to control cortex $(n=17)$, peritumoural tissue $(n=7)$, dysembryoplastic neuroepithelial tumours $(n=9)$ and astrocytomas (grade I-IV; subependymal giant cell astrocytomas, $n=10$; 
pilocytic astrocytoma, $n=15$; diffuse astrocytoma grade II, $n=10$; grade III, $n=14$ and glioblastoma $n=15$ ). Furthermore, the PI3K/AKT3/P21 pathway, which is predicated to be targeted by miR-519d and miR-4758, was deregulated in gangliogliomas. Functionally, overexpression of $\mathbf{m i R - 5 1 9 d}$ in an astrocytic cell line resulted in a downregulation of CDKN1A (P21) and an increase in cell proliferation, whereas cotransfection with miR-4758 counteracted this effect. These results suggest that miR519d and miR-4758 might work in concert as regulators of the cell cycle in low grade gliomas. Furthermore, these miRNAs could be used to distinguish gangliogliomas from dysembryoplastic neuroepithelial tumours and other low and high grade gliomas and may lead to more targeted therapy.

\section{INTRODUCTION}

Low-grade epilepsy-associated brain tumours (LEATs), including glioneuronal tumours (GNTs) such as gangliogliomas (GGs) and dysembryoplastic neuroepithelial tumours (DNTs), represent the most frequent tumour entity in young patients who undergo surgery for chronic intractable focal epilepsy [1-4].

Patients with LEATs often have a history of 2 or more years of drug-resistant epilepsy [5]. GGs and DNTs are low grade, stationary or very slow growing, cortical based tumours with a very low risk of tumour recurrence and malignant progression $[3,5]$. These tumours often present with early seizure onset at a mean age of 16.5 years $[1,2]$. In the majority of cases surgical resection shows favourable prognosis, both in terms of tumour management and seizure outcome. However, in a small proportion of cases, seizures may persist $[2,3,6]$.

The histopathological features of GNTs include a mixture of neuronal (dysplastic neurons) and glial elements in GGs, while a specific glioneuronal element is evident in DNTs $[3,7]$. Immature neural elements combined with expression of stem cell markers and the coexistence with cortical dysplasia suggest a developmental pathogenesis for GGs and DNTs. This is supported by studies indicating that these tumours are associated with molecular alterations of key developmental signalling pathways, including the enhanced activation of the mitogenactivated protein kinase/extracellular signal-regulated kinase (MAPK/ERK) and the phosphoinositide 3-kinase/ Protein Kinase B/mechanistic target of rapamycin (PI3K/ AKT/mTOR) pathway $[1,8-11]$. The $B R A F \mathrm{c} .1799 \mathrm{~T}>\mathrm{A}$ (p.V600E; BRAF V600E) mutation was found to be a common genetic driver in GGs (18-56\%). However, the frequency of this mutation varies considerably between studies $[8,12-15]$. In other LEATs, the BRAF mutation has been observed in $30-51 \%$ of DNTs $[13,15,16]$ and in $3 / 10$ of the recently described polymorphous low-grade neuroepithelial tumours of the young (PLNTY) [17], but not in multinodular and vacuolating neuronal tumours (MVNT) [18] and angiocentric gliomas [19]. In other low grade gliomas such as pleomorphic xanthoastrocytoma (PXA) and pilocytic astrocytomas (PA) the BRAF V600E mutation has also been observed $[8,20,21]$. Therefore, the presence of the $B R A F V 600 E$ mutation cannot be regarded as specific for any tumour entity. In contrast to the $B R A F$ V600E mutation, tyrosine kinase activating FGFR1 gene mutations were found more frequently in DNTs (58-82\%) $[9,19]$, suggesting this mutation could be a good marker for DNTs. However, besides the FGFR1 mutations, BRAF mutations and copy number abnormalities also occur in DNTs, making it difficult to distinguish between GGs and DNTs based only on the presence of BRAF and FGFR1 mutations [13, 15, 16, 22].

The 2016 revised WHO classification for LEATs is based on histological criteria, but does not involve an integration of molecular and pathological analysis techniques [1]. Although, several histological classification systems have been proposed [1-3], the broad spectrum of LEATs renders classification using these systems very difficult. Recently, a molecular classification was suggested for glioneuronal tumours, highlighting the importance of integrating molecular diagnostics in classifying these tumours $[23,24]$.

The aim of the present study was to find molecular markers that can be used to identify specific LEATs. The focus was on microRNAs (miRNAs), since they are important post-transcriptional regulators of gene expression, involved in the pathogenesis of different neurological diseases and oncogenesis [25-28]. In particular we investigated the expression and function of miR-519d and miR-4758, two miRNAs involved in the regulation of the PI3K/AKT3/P21 pathway, that could be used to distinguish GGs from DNTs and other low and high grade gliomas.

\section{RESULTS}

\section{Mutation analysis of GG and DNT}

The BRAF V600E mutation was found in 16 of the $26(61.5 \%)$ GG samples. An initial screen using sanger sequencing identified $11 \mathrm{GG}$ samples that were positive for the BRAF V600E mutation. Samples that were deemed $B R A F$ V600E negative based on sanger sequencing and of which a sufficient amount of DNA was still available were screened further using a next-generation sequencing panel. Based on this panel an additional 5 GG samples 
A

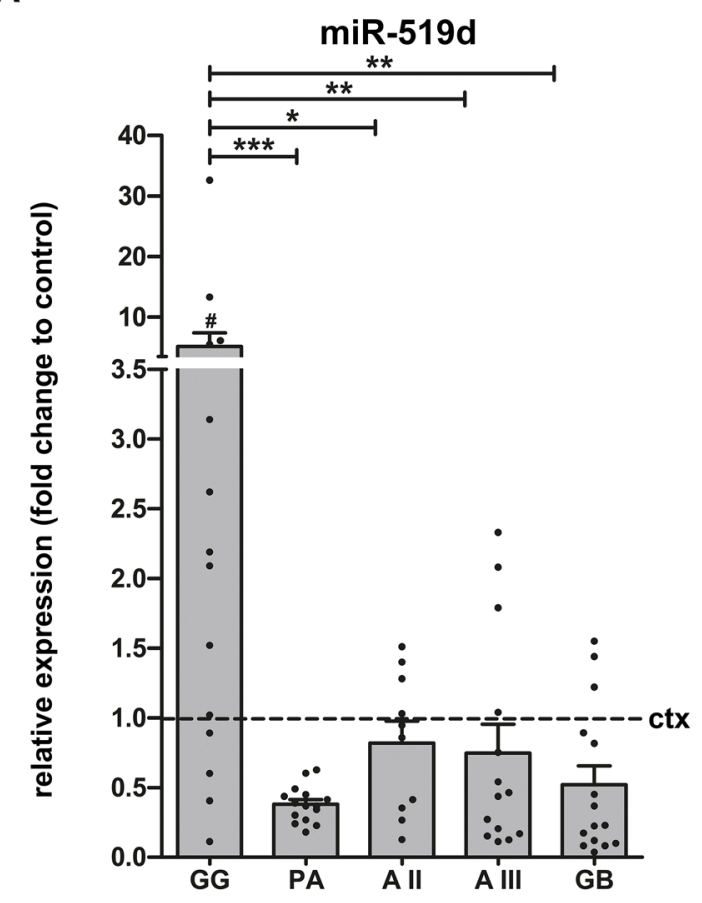

C

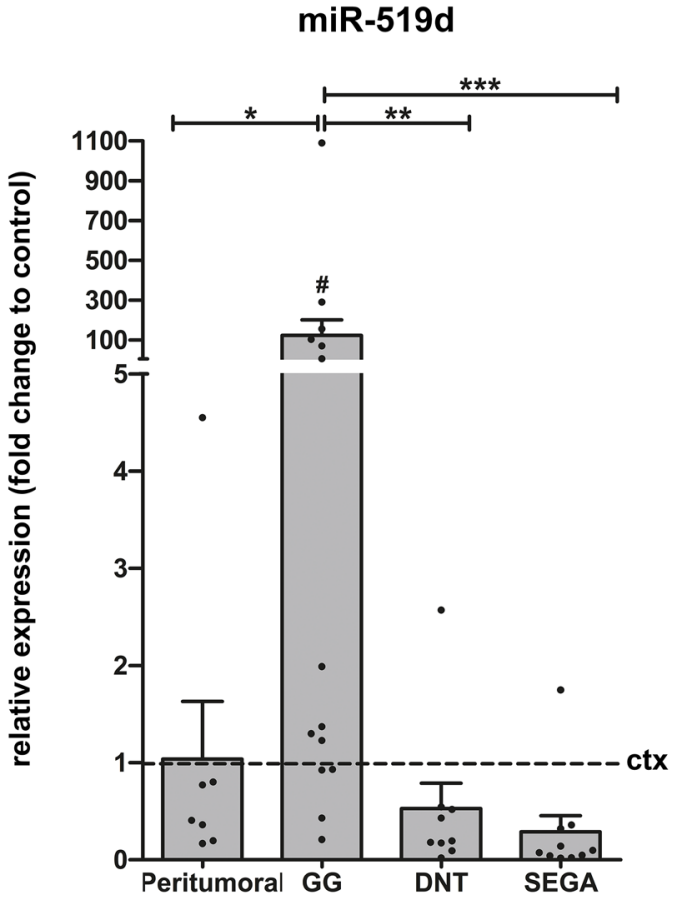

B

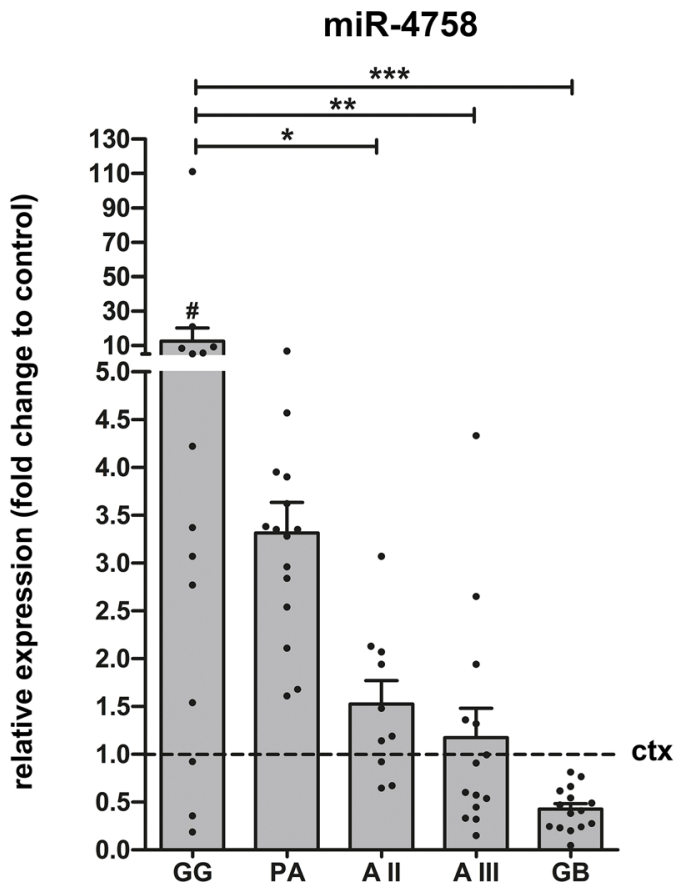

D

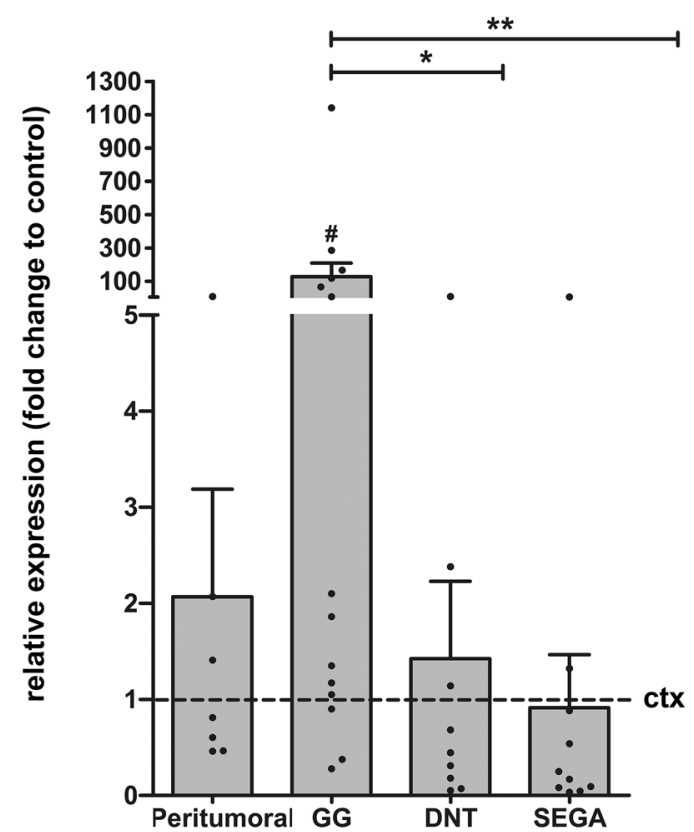

Figure 1: Relative expression of miR-519d and miR-4758 in GNTs and astrocytomas. Quantitative real-time PCR. Panels (A and B): Relative expression of miR-519d (A) and miR-4758 (B) in GG ( $\mathrm{n}=14)$, PA ( $\mathrm{n}=15)$, AII $(\mathrm{n}=10), \mathrm{AIII}(\mathrm{n}=14)$ and GB ( $\mathrm{n}=15)$. Data are expressed relative to the expression in control cortex ( $\mathrm{n}=7$; frozen material). Panels (C and $\mathbf{D})$ : Expression of miR-519d (C) and miR-4758 (D) in peritumoural GG $(n=7), G G(n=14)$, DNT $(n=9)$ and SEGA $(n=10)$; FFPE. Data are expressed relative to the expression in control cortex $(\mathrm{n}=9)$. miRNA expression was normalized to that of the U6B small nuclear RNA gene (Rnu6B) in all cohorts. Dots represent individual samples. The error bars represent SEM. " $\mathrm{p}<0.05 ;{ }^{* *} \mathrm{p}<0.01,{ }^{* * *} \mathrm{p}<0.001$ between experimental samples, Kruskal-Wallis test followed by Mann-Whitney U test; \#p $<0.05$ between GG and control cortex, Mann-Whitney U test. ctx: control cortex; GG: ganglioglioma; PA: pilocytic astrocytoma; AII: astrocytoma grade II; AIII: astrocytoma grade III; GB: glioblastoma; DNT: dysembryoplastic neuroepithelial tumour; SEGA: subependymal giant cell astrocytoma. 
were found to be positive for BRAF V600E. One BRAF $V 600 E$ positive $\mathrm{GG}$ also had an additional BRAF mutation (BRAF T559R) on the same allele. A total of 8 DNTs were also screened on the panel of which 1 was found positive for the BRAF V600E, 1 was found positive for FGFR1 mutations (FGFR1 G539R and FGFR1 K656E) and 1 was found positive for CIC G935R mutation of which the pathological implication is unknown.

\section{miR-519d and miR-4758 expression in GG}

First, we performed a global expression analysis of 1891 miRNAs using an Exiqon miRCURY LNA ${ }^{\text {TM }}$ microRNA Array on 11 frozen brain samples (control cortex, $\mathrm{n}=5$; GGs, $\mathrm{n}=6$ ). Compared to control cortex, a total of 5 miRNAs: miR-519d, miR-4758, miR-664b, miR-4714 and miR-5681b were differentially expressed in GGs. We further validated these 5 miRNAs using Taqman miRNA assays in a larger cohort (frozen samples, control cortex, n=7; GG, n=14). Only miR-519d and miR-4758 were confirmed to be differentially expressed in GGs compared to control cortex, showing 5-fold and 13-fold upregulation $(\mathrm{p}=0.0335$ and $\mathrm{p}=0.0153$, respectively; Figure 1A-1B). Receiver operating characteristic (ROC) analysis for miR-519d yielded an area under the curve (AUC) of 0.796, $\mathrm{p}=0.031$ and for $\mathrm{miR}-4758 \mathrm{AUC}=0.837$, $\mathrm{p}=0.0139$. Furthermore, a positive correlation was observed between the two miRNAs ( $r=0.731, p=0.0002)$. We also evaluated the expression of both miRNAs in GG compared to other gliomas, including PA $(n=15)$, diffuse astrocytoma grade II (AII; $n=10)$, diffuse astrocytoma grade III (AIII; $n=14$ ) and glioblastoma (GB; $n=15$; Figure 1A-1B). miR-519d was upregulated in GG compared to all other gliomas, whereas miR-4758 was upregulated compared to AII, AIII, GB but not PA. Furthermore, no difference was found in expression of both miRNAs in $B R A F$ V600E mutated GGs $(\mathrm{n}=8)$ compared to wildtype GGs ( $\mathrm{n}=6 ; \mathrm{p}=0.950$ and $\mathrm{p}=0.414$; data not shown).

\section{miR-519d and miR-4758 expression by quantitative real-time PCR in GG, DNT and subependymal giant cell astrocytoma}

Recent studies indicate a robust stability of miRNAs, supporting the accuracy of miRNA measurements with quantitative real-time PCR, also in formalin-fixed paraffinembedded (FFPE) tissues [29-31]. Therefore, miR-519d and miR-4758 expression was also evaluated in a large cohort of FFPE samples, including control cortex $(n=9)$, GG $(n=14)$, peritumoural cortex $(n=7)$, DNT $(n=9)$ and subependymal giant cell astrocytoma (SEGA; $n=10$ ) samples. Normal appearing peritumoural tissue represents appropriate disease control tissue for GG, since it is exposed to the same seizure activity, drugs and fixation time, while

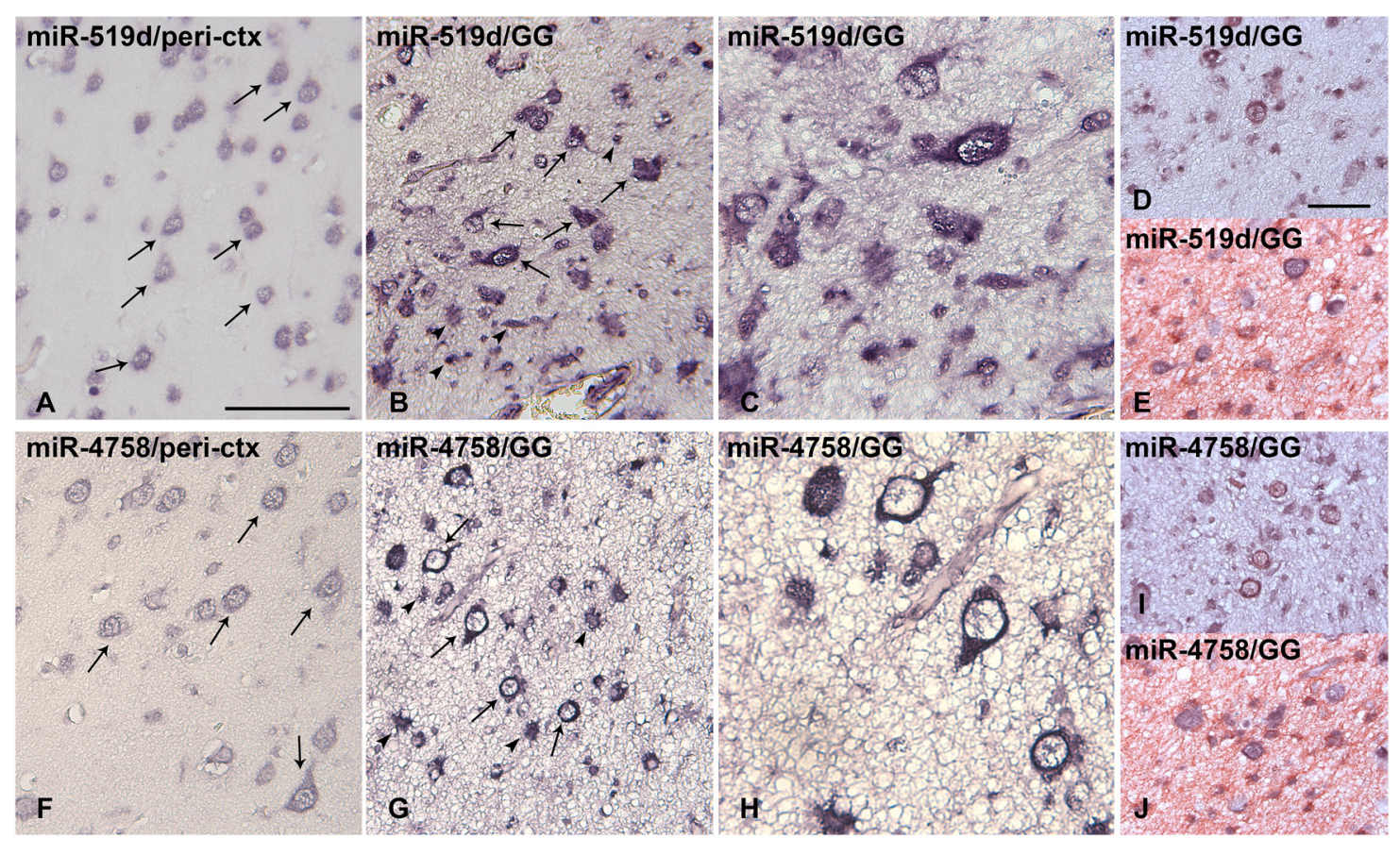

Figure 2: In situ hybridization of miR-519d and miR-4758 expression in peritumoural cortex and ganglioglioma. Panels (A and F): Normal appearing peritumoural cortex (ctx); miR-519d (A) and miR-4758 (F) were weakly expressed in neurons (arrows) and could not be detected in glial cells. Panels (B-C) and (G-H): GG; miR-519d (B-C) and miR-4758 (G-H) were expressed in both the neuronal (arrows) and the glial (arrowheads) tumour components; Panels D and I show expression of miR-519d (D) and miR-4758 (I) in neurons (NeuN-positive, red) panels E and J show expression of miR-519d (E) and miR-4758 (J) in astrocytes (GFAP-positive, red) GG: ganglioglioma. Scale bar in A: $100 \mu \mathrm{m}$ in A-B and F-G, $50 \mu \mathrm{m}$ in C and H; scale bar in D: $50 \mu \mathrm{m}$ in D-E and I-J. 
also being of identical age and gender. Evaluation of miR$519 \mathrm{~d}$ and miR-4758 expression in this cohort confirmed the upregulation of miR-519d in GG compared to control cortex $(p=0.041)$, DNT, SEGA and peritumoural cortex, whereas miR4768 was upregulated in GG compared to control cortex $(p=0.035)$, DNT and SEGA but not when compared to peritumoural cortex (Figure 1C-1D).

\section{miR-519d and miR-4758 cellular distribution by in situ hybridization in GG}

The cellular distribution of miR-519d and miR4758 in peritumoural tissue $(n=6)$ and GG $(n=7)$ was investigated using in situ hybridization (ISH). In peritumoural tissue a weak expression of miR-519d and miR-4758 was observed in neuronal cells, but could not be detected in glial cells (Figure 2A and 2F). Expression of both miR-519d and miR-4758 was found specifically in cells with atypical astroglia morphology and in dysplastic neurons (Figure 2B-2C and 2G-2H). Double labelling confirmed miR-519d and miR-4758 expression in NeuNpositive neurons and GFAP-positive astrocytes in GG (Figure 2D-2E and 2I-2J).

A

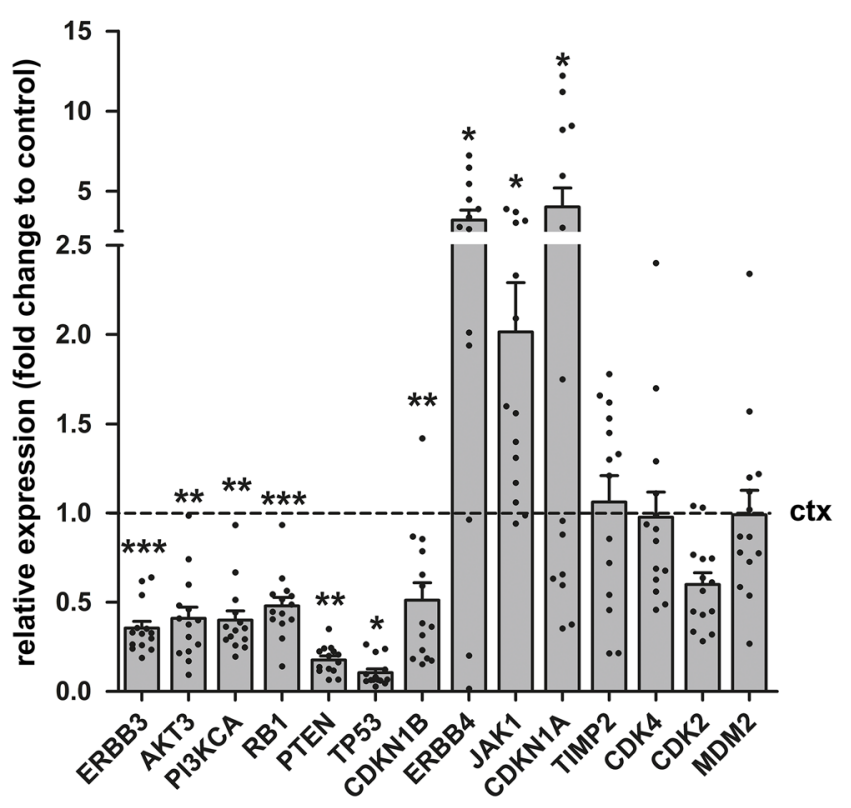

\section{miRNA target expression in GG}

In order to identify potential targets of miR-519d and miR-4758 5 different databases were utilised. Targets were considered relevant if found in at least 3 of the 5 databases. Based on these target prediction tools, AKT3, CDKN1A (P21), JAK1, PTEN, ERBB3, ERBB4, RB1 and TIMP2 were identified as potential targets of miR519d. Both clinical and experimental studies have shown the potential contribution of miR-519d dysregulation in hepatocellular carcinoma, breast cancer and cervical cancer [32-34]. AKT3, CDKN1A and PTEN have all been shown to be downregulated by miR-519d, potentially explaining the oncogenic features of this miRNA $[35,36]$. Based on target prediction tools the relatively unknown miRNA, miR-4758 was predicted to target $C D K 2$ and $C D K N 1 B(\mathrm{P} 27)$, raising the possibility that $\mathrm{miR}-4758$ also has oncogenic properties. Evaluation of the mRNA expression of miR-519d and miR-4758 targets (Figure 3) showed a downregulation of ERBB3 ( $\mathrm{p}=0.0005), A K T 3$ $(\mathrm{p}=0.0015), P I 3 K C A(\mathrm{p}=0.0015), R B 1(\mathrm{p}=0.0009), P T E N$ $(\mathrm{p}=0.0041), \operatorname{TP} 53(\mathrm{p}=0.023)$ and $C D K N 1 B(\mathrm{p}=0.0065)$ in GG ( $\mathrm{n}=14$, except for ERBB4 where $\mathrm{n}=13)$ compared to

B

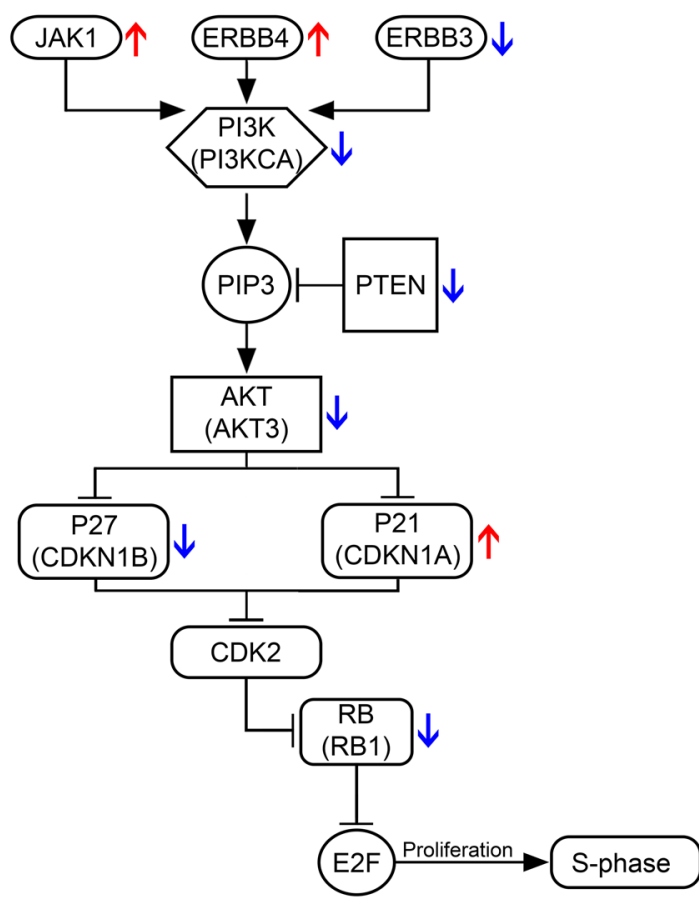

Figure 3: Relative expression of miR-519d and miR-4758 target genes in ganglioglioma. Quantitative real-time PCR of ERBB3, AKT3, PI3KCA, RB1, PTEN, TP53, CDKN1B, ERBB4, JAK1, CDKN1A, TIMP2, CDK4, CDK2 and MDM2 in GG (n=14, except for $E R B B 4$ where $\mathrm{n}=13)$ compared to control cortex $(\mathrm{n}=7)$. Panel (A) shows increased mRNA expression of $E R B B 4, J A K 1$ and $C D K N 1 A$ and decreased mRNA expression of ERBB3, AKT3, PI3KCA, RB1, PTEN, TP53 and CDKN1B in GG compared to control cortex. The expression of TIMP2, CDK4,CDK2 and MDM2 did not change. Data are expressed relative to the expression observed in control cortex. mRNA expression was normalized to that of EFl $\alpha$. Dots represent individual samples. The error bars represent SEM; statistical significance: ${ }^{*} \mathrm{p}<0.05 ;{ }^{* *} \mathrm{p}<0.01,{ }^{* * *} \mathrm{p}<0.001$, Kruskal-Wallis test followed by Mann-Whitney U test. ctx: control cortex. GG: ganglioglioma. Panel (B) shows a schematic overview of the PI3K pathway. The red arrows indicate the upregulation of genes and the blue arrows the downregulation of genes as indicated in panel A. 
control cortex ( $\mathrm{n}=7$; Mann-Withney $\mathrm{U}$ test). Furthermore, targets $E R B B 4(\mathrm{p}=0.032) C D K N 1 A(\mathrm{p}=0.048)$ and $J A K 1$ $(\mathrm{p}=0.0124)$ were found to be upregulated in GG compared to control cortex. The expression of TIMP2 $(\mathrm{p}=0.68)$, $C D K 4(\mathrm{p}=0.39), C D K 2(0.91)$ and MDM2 $(\mathrm{p}=0.63)$ did not change.

\section{miRNA target expression in cell culture}

Given the lack of GG cell lines, we used the human pediatric low grade astrocytoma cell line Res259 (LGG2) obtained from a pediatric AII [37] to investigate the effects of miR-519d and miR-4758 upregulation. After transfection with miRNA mimic, overexpression of the specific miRNA was observed under basal condition (data not shown). Quantitative real-time PCR analysis was performed to evaluate the effects of miR-519d and miR-4758 transfection on mRNA expression of a subset of targets related to the PI3K/AKT pathway, involved in the regulation of cell cycle progression [38]. CDKN1A was downregulated after miR-519d transfection, whereas transfection with miR-4758 did not affect CDKN1A expression compared to control (Figure 4A). Cotransfection of miR-519d with miR-4758 rescued the effect of miR-519d transfection. The expression of miR4758 target $C D K N 1 B$ was not affected by transfection with miR-4758 or miR-519d alone (Figure 4B). However, after co-transfection with miR-4758 and miR-519d CDKN1B
A

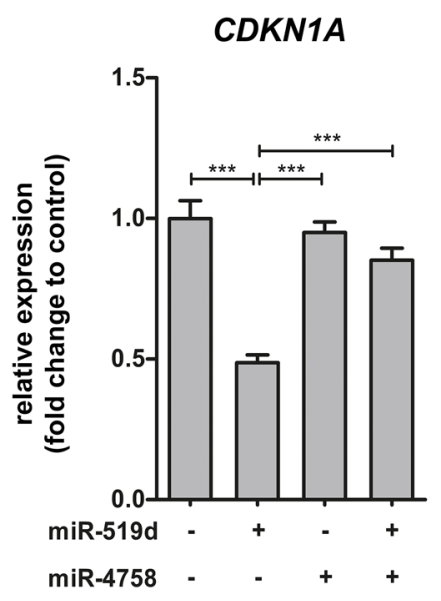

D

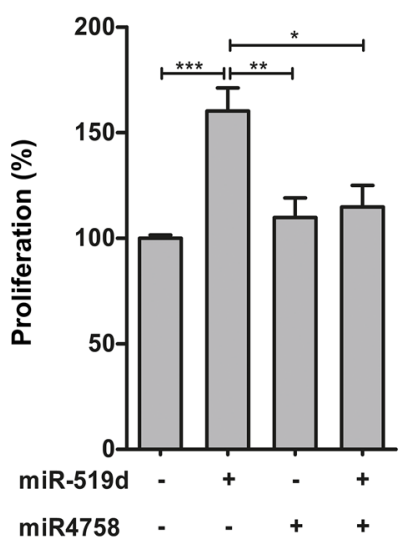

B

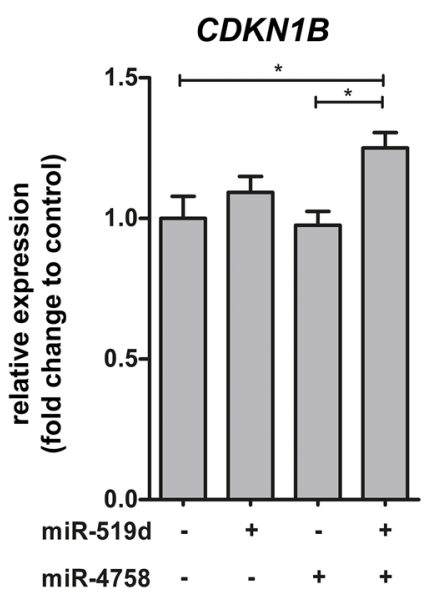

C

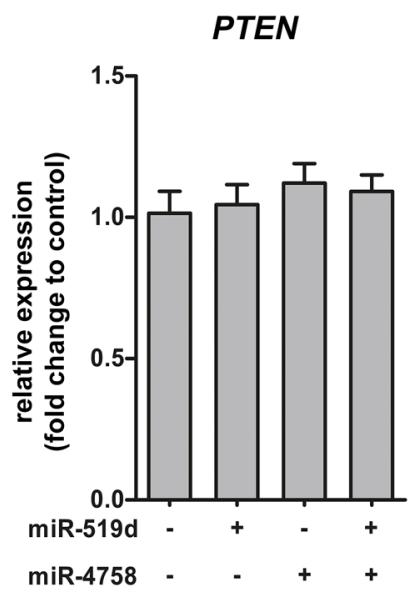

Figure 4: miR-519d and miR-4758 target mRNA expression and the regulation of cell cycle in cell culture. Panels (A-C): Relative expression of CDKN1A (A), CDKN1B (B) and PTEN (C) after transfection of LGG2 cell line for 24 hours with lipofectamine $(\mathrm{n}=5)$, miR-519d mimic $(\mathrm{n}=4)$, miR-4758 mimic $(\mathrm{n}=5)$ or miR-519d mimic co-transfected with miR-4758 mimic $(\mathrm{n}=5)$. Panel (D): The S phase of cell cycle progression after transfection with lipofectamine $(n=7)$, miR-519d $(n=7)$, miR-4758 $(n=8)$ and miR-519d $(n=7)$ cotransfected with miR-4758 in LGG2. miR-519d transfected LGG2 cells displayed an increased S phase compared to the negative control. miR-4758 transfected cultures displayed no alteration in S phase. Co-transfection of miR-519d and miR-4758 was able to mimic the response of the negative control. The error bars represent SEM; statistical significance: ${ }^{*} \mathrm{p}<0.05 ;{ }^{* *} \mathrm{p}<0.01,{ }^{* * *} \mathrm{p}<0.001$, Kruskal-Wallis test followed by Mann-Whitney U test. 


\begin{tabular}{|c|c|c|c|c|c|c|c|c|c|}
\hline Patient & Diagnose & Gender & Localization & $\begin{array}{l}\text { Age of surgery } \\
\text { (years) }\end{array}$ & $\begin{array}{c}\text { Age of } \\
\text { seizure onset } \\
\text { (years) }\end{array}$ & $\begin{array}{c}\text { Duration } \\
\text { of } \\
\text { epilepsy } \\
\text { (years) }\end{array}$ & $\begin{array}{c}\text { Pre-operative } \\
\text { seizure } \\
\text { frequency } \\
\text { (per month) }\end{array}$ & $\begin{array}{c}\text { Post- } \\
\text { operative } \\
\text { outcome } \\
\text { (Engel's } \\
\text { score) }\end{array}$ & Mutation \\
\hline $1^{\mathrm{a}, \mathrm{c}}$ & GG & $\mathrm{F}$ & $\mathrm{T}$ & 29 & 13 & 16 & 200 & 1 & BRAF V600E \\
\hline $2^{\mathrm{a}, \mathrm{c}}$ & GG & $\mathrm{F}$ & $\mathrm{T}$ & 11 & 8 & 3 & 56 & 1 & BRAF V600E \\
\hline $3^{\mathrm{a}, \mathrm{c}}$ & GG & M & $\mathrm{T}$ & 16 & 14 & 2 & 30 & 1 & BRAF V600E \\
\hline $4^{a, c}$ & GG & $\mathrm{F}$ & $\mathrm{T}$ & 42 & 11 & 31 & 60 & 1 & NMI \\
\hline $5^{a, b, c}$ & GG & M & $\mathrm{T}$ & 21 & 13 & 8 & 70 & 2 & BRAF V600E \\
\hline $6^{\mathrm{a}, \mathrm{c}}$ & GG & $\mathrm{F}$ & $\mathrm{T}$ & 14 & 11 & 3 & 55 & 1 & $\begin{array}{c}B R A F T 559 R \\
\text { and } B R A F \\
V 600 E^{*}\end{array}$ \\
\hline $7^{\mathrm{a}, \mathrm{b}}$ & GG & $\mathrm{F}$ & $\mathrm{P}$ & 24 & 24 & 0 & 3 & 1 & BRAF V600E \\
\hline $8^{\mathrm{a}, \mathrm{c}}$ & GG & $\mathrm{F}$ & $\mathrm{T}$ & 23 & 14 & 9 & 60 & 1 & BRAF V600E \\
\hline $9^{a}$ & GG & $\mathrm{F}$ & $\mathrm{T}$ & 19 & 15 & 4 & 70 & 1 & NMI \\
\hline $10^{\mathrm{a}}$ & GG & M & $\mathrm{T}$ & 18 & 13 & 5 & 20 & 1 & BRAF V600E \\
\hline $11^{\mathrm{a}, \mathrm{b}}$ & GG & M & $\mathrm{P}$ & 28 & 28 & 0 & 80 & 1 & BRAF V600E \\
\hline $12^{\mathrm{a}}$ & GG & $\mathrm{F}$ & $\mathrm{T}$ & 34 & 11 & 23 & 90 & 1 & NMI \\
\hline $13^{\mathrm{a}}$ & GG & M & $\mathrm{T}$ & 20 & 11 & 9 & 160 & 1 & BRAF V600E \\
\hline $14^{\mathrm{a}}$ & GG & $\mathrm{F}$ & $\mathrm{T}$ & 49 & 19 & 30 & 150 & 1 & BRAF V600E \\
\hline $15^{\mathrm{b}}$ & GG & $\mathrm{F}$ & $\mathrm{T}$ & 28 & 12 & 16 & 30 & 2 & BRAF V600E \\
\hline $16^{\mathrm{b}}$ & GG & M & $\mathrm{T}$ & 10 & 9 & 1 & 30 & 1 & BRAF V600E \\
\hline $17^{\mathrm{b}}$ & GG & M & $\mathrm{T}$ & 18 & 17 & 1 & $<5$ & 1 & NMI \\
\hline $18^{\mathrm{b}}$ & GG & M & $\mathrm{T}$ & 44 & 20 & 24 & 10 & 1 & NMI \\
\hline $19^{\mathrm{b}}$ & GG & $\mathrm{F}$ & $\mathrm{T}$ & 6 & 3 & 3 & $10-20$ & 1 & NMI \\
\hline $20^{\mathrm{b}}$ & GG & M & $\mathrm{P}$ & 42 & 1 & 41 & $>30$ & 1 & NMI \\
\hline $21^{\mathrm{b}}$ & GG & $\mathrm{F}$ & B & 29 & No seizures & -- & -- & -- & NMI \\
\hline $22^{\mathrm{b}}$ & GG & M & $\mathrm{T}$ & 33 & 18 & 15 & -- & 1 & NMI \\
\hline $23^{\mathrm{b}}$ & GG & $\mathrm{F}$ & $\mathrm{T}$ & 22 & 10 & 12 & -- & 1 & NMI \\
\hline $24^{b}$ & GG & $\mathrm{F}$ & $\mathrm{C}$ & 48 & No seizures & -- & -- & -- & BRAF V600E \\
\hline $25^{\mathrm{b}}$ & GG & M & $\mathrm{T}$ & 34 & 16 & 22 & $<5$ & 1 & BRAF V600E \\
\hline $26^{\mathrm{b}}$ & GG & $\mathrm{F}$ & $\mathrm{T}$ & 56 & 52 & 4 & $80-100$ & 2 & BRAF V600E \\
\hline $27^{\mathrm{a}}$ & DNT & $\mathrm{F}$ & $\mathrm{T}$ & 15 & 11 & 4 & $>50$ & 1 & NMI \\
\hline $28^{\mathrm{a}}$ & DNT & $\mathrm{M}$ & $\mathrm{T}$ & 41 & 19 & 22 & $<5$ & 1 & NMI \\
\hline $29^{\mathrm{a}}$ & DNT & M & $\mathrm{T}$ & 11 & 10 & 1 & $10-20$ & 1 & $\begin{array}{l}\text { Mutation } \\
\text { unknown }\end{array}$ \\
\hline $30^{\mathrm{a}}$ & DNT & $\mathrm{M}$ & $\mathrm{T}$ & 8 & 2 & 6 & $>30$ & 1 & NMI \\
\hline $31^{\mathrm{a}}$ & DNT & $\mathrm{F}$ & $\mathrm{T}$ & 30 & 25 & 5 & $5-10$ & 4 & BRAF V600E \\
\hline $32^{\mathrm{a}}$ & DNT & $\mathrm{F}$ & $\mathrm{F}$ & 11 & 8 & 3 & $10-20$ & 1 & CIC G935R \\
\hline $33^{\mathrm{a}}$ & DNT & $\mathrm{F}$ & $\mathrm{T}$ & 16 & 14 & 2 & $<5$ & 1 & $\begin{array}{c}\text { NMI } \\
\text { (Continued) }\end{array}$ \\
\hline
\end{tabular}




\begin{tabular}{|c|c|c|c|c|c|c|c|c|c|}
\hline Patient & Diagnose & Gender & Localization & $\begin{array}{c}\text { Age of surgery } \\
\text { (years) }\end{array}$ & $\begin{array}{c}\text { Age of } \\
\text { seizure onset } \\
\text { (years) }\end{array}$ & $\begin{array}{c}\text { Duration } \\
\text { of } \\
\text { epilepsy } \\
\text { (years) }\end{array}$ & $\begin{array}{c}\text { Pre-operative } \\
\text { seizure } \\
\text { frequency } \\
\text { (per month) }\end{array}$ & $\begin{array}{c}\text { Post- } \\
\text { operative } \\
\text { outcome } \\
\text { (Engel's } \\
\text { score) }\end{array}$ & Mutation \\
\hline $34^{\mathrm{a}}$ & DNT & M & $\mathrm{T}$ & 35 & 17 & 18 & $>30$ & 1 & $\begin{array}{c}F G F R 1 \\
G 539 R \text { and } \\
F G F R 1 \\
\text { K656E }\end{array}$ \\
\hline $35^{\mathrm{a}}$ & DNT & $\mathrm{F}$ & $\mathrm{T}$ & 15 & 5 & 10 & $>50$ & 1 & NMI \\
\hline
\end{tabular}

M male, F female, F frontal, T temporal, P parietal, B brainstem, C cerebellum, NMI no mutation identified; ${ }^{a}$ FFPE (formalin-fixed, paraffin-embedded) tissue; ${ }^{b}$ Frozen tissue; ${ }^{~}$ Peritumoural cortex tissue. Gangliogliomas (GG) and dysembryoplastic neuroepithelial tumours (DNT). "Both mutations are on the same allel.

was upregulated compared to control. Furthermore, PTEN mRNA expression did not change after transfection with either one of the miRNAs (Figure 4C).

\section{Effects of miR-519d and miR-4758 modulation on the cell cycle}

We further evaluated the role of miR-519d and miR-4758 on cell cycle progression using flow cytometry analysis in Res259/LGG2. Overexpression of miR-519d showed a decreased $\mathrm{G}_{1}$ phase $(13 \%, p<0.01)$ whereas, transfection with miR-4758 resulted in an increased $\mathrm{G}_{2} / \mathrm{M}$ phase. Overexpression of miR-519d, but not miR-4758, increased the S phase; miR-4758 mimic co-transfected with miR-519d mimic was able to counteract the effect of miR-519d alone (Figure 4D).

\section{DISCUSSION}

In this study, we showed that miR-519d and miR4758 are specifically upregulated in GGs compared to control tissue, DNTs and other gliomas. In addition, we showed that the PI3K/AKT3/P21 pathway was deregulated in GGs. Importantly, we observed a downregulation of CDKN1A (P21) and an increase in cell proliferation after miR-519d overexpression in an astrocytic cell line, whereas co-transfection with miR-4758 counteracted this effect, suggesting an oncogenic function of miR-519d.

GNTs represent a major cause of medically intractable epilepsy in young patients, however their underlying biology remains to be fully investigated. The 2016 revised WHO classification includes histopathological criteria for LEATs [1, 7]. However, the different GNTs are difficult to distinguish by their histological features even by experienced pathologists $[1,3]$. Improving the classification and the ability to distinguish LEATs from IDH1/2-wildtype low-grade gliomas is becoming more important to avoid unnecessary treatment with chemo-radiation therapy $[1,39]$. Due to the current limitations in the classification of LEATs there is a need for developing accurate molecular techniques that can be used for diagnosis. In this study we evaluated the role of miRNAs in distinguishing GGs from DNTs and other gliomas. We found two miRNAs, miR-519d and miR-4758, upregulated in GGs compared to control tissue, DNTs and other gliomas. Therefore, these two miRNAs could be considered as additional markers in the classification of LEATs, especially in distinguishing GGs from DNTs and other low and high grade gliomas.

Recently, it was suggested that glioneuronal tumours can be separated into two groups: one group enriched for $B R A F$ mutations with an astrocytic expression phenotype and one group enriched for FGFR1 mutations with an oligodendrocyte precursor expression phenotype [23]. It would be interesting to see how miR-519d and miR-4758 are expressed in the two groups as suggested by Stone et al., 2018. Here, we evaluated the expression of both miRNAs in BRAF mutated GGs and GGs in which no mutation could be identified and we were unable to find any differences.

Using online prediction databases we identified the PI3K/AKT3/P21 pathway as a predicted target of both miR-519d and miR-4758. Next, we showed that the genes related to the PI3K/AKT3/P21 pathway were differentially expressed in GGs compared to control tissue, indicating that this pathway is deregulated in GGs. Overexpression experiments with miR-519d and miR-4758 indicate that overexpression of miR-519d increased proliferation, which could be explained by the downregulation of $C D K N 1 A$, a key player of the PI3K/AKT3/P21 pathway. This is in agreement with previous studies showing that downregulation of CDKN1A, a direct target of miR$519 \mathrm{~d}$, results in increased proliferation $[35,36,40]$. Overexpression of miR-4758 rescued the expression of $C D K N 1 A$ and the associated increase in proliferation due to miR-519d, suggesting a tumour suppressive role for miR-4758. However, transfection of miR-4758 did not downregulate the predicted target gene $C D K N 1 B$, highlighting the limitations and the challenges posed by the interpretation of miRNA overexpression experiments 
to achieve insights into the function of specific miRNAs in the regulation of the cell cycle. Therefore, the exact mechanism behind the rescue effect of miR-4758 is yet to be elucidated and requires further investigation.

The upregulation of $C D K N 1 A$ in GGs along with the slow growing phenotype of GGs could potentially be attributed to the opposing oncogenic properties of miR$519 \mathrm{~d}$ and miR-4758. It must be noted that based on our experiments we cannot exclude both miRNAs targeting other genes related to the PI3K/AKT3/P21 pathway affecting GG proliferation.

Overall, our results indicate that miR-519d and miR4758 are potential regulators of the cell cycle and therefore could play a role in formation of GGs. Furthermore, we showed that these miRNAs could be used as markers to distinguish GGs from DNTs and other low and high grade gliomas, which has implications for determining targeted therapeutic strategies and could prevent unnecessary treatment with chemo-radiation therapy. However, to determine the diagnostic value of these molecular markers in distinguishing GGs from DNTs, these miRNAs need to be validated in larger multicenter cohorts that include difficult-to-classify LEAT subtypes.

\section{MATERIALS AND METHODS}

\section{Subjects}

The majority of the cases included in this study were obtained from the archives of the Academic Medical Center of Amsterdam and the University Medical Center Utrecht. A further DNT case was included from the University College London Institute of Neurology. SEGA tissue was obtained from the following institutes: University Hospital Erlangen, Children's Memorial Health Institute in Warsaw, Hacettepe University in Ankara, and the University Hospital de Santa Maria (CHLN) in Lisbon. A total of 99 surgical tumour specimens were examined (Table 1; n=35 GNTs (WHO grade I); n= 64 astrocytomas; SEGA (TSC1/TSC2 mutated) n=10; PA (WHO I) n=15; AII (IDH-1 mutant) n=10; AIII (IDH-1 mutant) $\mathrm{n}=14$ and GB (IDH-1 WT) n=15). Eight surgical specimens contained sufficient amount of peritumoural tissue (normal-appearing cortex/white matter adjacent to the tumour; Table 1). All tumour cases were reviewed independently by eight neuropathologists, and the diagnosis was confirmed according to the revised WHO classification of tumours of the central nervous system $[1,7]$; only entities with consensus agreement between the neuropathologists were included (CD34 positive GGs and CD34 negative DNTs, all IDH1 negative). Additional molecular diagnosis was performed on GNT samples with sufficient amounts of DNA to identify mutations in $B R A F$ and FGFR1 genes. Control cortical specimens were obtained at autopsy from 17 patients. For the cortical specimens attention was taken to provide equal grey/white matter tissue components. For control tissue, all autopsies were performed within 24 hours after death. Tissue was obtained and used in accordance with the Declaration of Helsinki and the AMC Research Code provided by the Medical Ethics Committee and approved by the science committee of the UMC Utrecht Biobank.

\section{Mutation analysis}

GG samples were screened using sanger sequencing as described previously [41]. Next generation sequencing (NGS) was performed on 10 GGs and 8 DNTs using a customised Ion AmpliSeq ${ }^{\mathrm{TM}}$ Neurology Panel (ThermoFisher Scientific, Waltham, Massachusetts, USA) for targeted multi-gene amplification, as previously reported [18]. This panel consists of the following genes; $A K T 1$, AKT3, ATRX, BRAF, CDK6, CIC, CTNNB1, DDX3X, DEPDC5, EZH2, FGFR1 (exon 12 and exon 14), FUBP1, H3F3A, HIST1H3b, HIST1H3c, IDH1, IDH2, KDM6A, mTOR, MYB, MYBL1, NPRL2, NPRL3, PIK3CA, PIK3R1, PIK3R2, PTCH1, PTEN, SMARCA4, SMARCB1, SMO, SUFU, TP53. FGFR1 mutations below 5\%, duplications and fusion genes cannot be detected with this panel.

\section{Tissue preparation}

Brain tissue from control and tumour patients was fixed in $10 \%$ buffered formalin and embedded in paraffin. Paraffin-embedded tissue was sectioned at $5 \mu \mathrm{m}$ and mounted on pre-coated glass slides (Star Frost, Waldemar Knittel GmbH, Brunschweig, Germany). Sections of all specimens were processed for hematoxylin and eosin (HE), staining as well as for immunohistochemical stainings for a number of neuronal and glial markers to confirm the diagnosis. Additional tissue from controls $(n=8)$ and from patients with GG $(n=15)$, PA $(n=15)$, AII $(n=10)$, AIII $(n=14)$ and $G B(n=15)$ was snap frozen in liquid nitrogen and stored at $-80^{\circ} \mathrm{C}$ until further use (RNA isolation for microRNA array and/or quantitative real-time PCR).

\section{In situ hybridization}

ISH for miR-519d and miR-4758 was performed using 5' - 3' double digoxygenin (DIG)-labeled Superior probes (miR-519d-3p; DIG-CacTcuAaaGggAggCacTuuGDIG; miR-4758-3p: DIG-GagGguGguCagCagGugGggCaDIG; Ribotask ApS, Odense, Denmark). The hybridizations were done on $5 \mu \mathrm{m}$ sections of paraffinembedded materials as described previously [30]. The probes were hybridized at $58^{\circ} \mathrm{C}$ for $1 \mathrm{~h}$, and the hybridization was detected with alkaline phosphatase (AP)-labeled anti-DIG (Roche Applied Science, Basel, Switzerland). NBT (nitro-blue tetrazolium chloride)/ BCIP (5-bromo-4-chloro-3'-indolyphosphate p-toluidine salt) was used as chromogenic substrate for AP. Negative control assays were performed without probes and without primary antibody (sections were blank). For double- 
staining, combining immunohistochemistry with ISH, the sections were first processed for ISH and then processed for immunohistochemistry with glial fibrillary acidic protein (GFAP; monoclonal mouse, Sigma, St. Louis, Mo, USA; 1:4000), and NeuN (neuronal nuclear protein; mouse clone MAB377; Chemicon, Temecula, CA, USA; 1:2000). Signal was detected using the chromogen 3-amino-9ethylcarbazole (Sigma-Aldrich, St. Louis, MO, USA).

\section{RNA isolation}

For RNA isolation, cells or frozen tissue were homogenized in Qiazol Lysis Reagent (Qiagen Benelux, Venlo, The Netherlands). Total RNA, including the miRNA fraction, was isolated using the miRNeasy Mini kit (Qiagen Benelux, Venlo, the Netherlands) according to manufacturer's instructions. The concentration and purity of RNA were determined using a Nanodrop spectrophotometer (Thermo Fisher Scientific, Wilmington, DE, USA). FFPE material was processed for RNA isolation using QuickExtract ${ }^{\mathrm{TM}}$ FFPE RNA Extraction Kit (Epicentre, Madison, WI, USA) according to manufacturer's instructions. The concentration of RNA was determined using a Qubit ${ }^{\circledR}$ 2.0 Fluorometer (Life Technologies, Carlsbad, CA, USA).

\section{MicroRNA microarrays}

A screening for miRNAs was performed using the miRCURY LNA ${ }^{\mathrm{TM}}$ microRNA array (7th gen, Cat \# 208500, Exiqon, Vedbaek, Denmark) by the Exiqon miRNA array service. Briefly, $5 \mu \mathrm{g}$ of total RNA from 6 GG and 5 control cortex samples were labelled using the miRCURY LNA ${ }^{\mathrm{TM}}$ microRNA Hi-Power Labeling Kit, Hy $3^{\mathrm{TM}} / \mathrm{Hy} 5^{\mathrm{TM}}$ and hybridized on the miRCURY LNA ${ }^{\mathrm{TM}}$ microRNA Array. After washing, the slides were scanned and analysed using ImaGene ${ }^{\circledR} 9$ (miRCURY LNA ${ }^{\text {TM }}$ microRNA Array Analysis Software, Exiqon, Vedbaek, Denmark). The quantified signals were corrected for background (Normexp with offset value 10 [42]), and normalized using the global Lowess (Locally Weighted Scatterplot Smoothing) regression algorithm.

\section{MicroRNA target prediction}

Using the online database miRWalk (version 2.0; http://zmf.umm.uni-heidelberg.de/apps/zmf/mirwalk/) a total of 5 different databases (miRWalk, Microt4, miRanda, miRDB and Targetscan) were used to identify predicted targets of miR-519d and miR-4758. Targets were considered relevant if found in at least 3 of the 5 databases.

\section{Quantitative real-time PCR analysis}

miRNA (miR-519d-3p, miR-4758-3p, miR-664b3p, miR-4714-5p, miR-5681b and a reference gene, U6B small nuclear RNA gene, Rnu6B) expression was analyzed using Taqman microRNA assays (Applied Biosystems,
Foster City, CA, USA). cDNA was generated using the Taqman MicroRNA reverse transcription kit (Applied Biosystems, Foster City, CA, USA) according to the manufacturer's instructions, and the PCRs were run on a Roche Lightcycler 480 thermocycler (Roche Applied Science, Basel, Switzerland).

To evaluate miRNA targets (TIMP2, AKT3, ERBB3, ERBB4, PI3KCA, TP53, MDM2, CDK4, RB1, CDK2, CDKN1A (P21), CDKN1B (P27), JAK1 and PTEN), 1 $\mu \mathrm{g}$ of cell culture derived total RNA or $500 \mathrm{ng}$ of human brain material-derived total RNA were reverse-transcribed into cDNA using oligo dT primers (Supplementary Table 1). EFl $\alpha$ was used as a reference gene. PCRs were run as described previously [43] on a Roche Lightcycler 480 thermocycler (Roche Applied Science, Basel, Switzerland).

Quantification was performed using the computer program LinRegPCR in which linear regression on the Log (fluorescence) per cycle number data is applied to determine the amplification efficiency per sample [44, 45]. The starting concentration of each specific product was divided by the starting concentration of reference genes and this ratio was compared between groups.

\section{Cell transfection}

The human pediatric low grade astrocytoma cell line (WHO grade II: Res-259; LGG2) was kindly provided by Dr Chris Jones (Institute of Cancer Research, Sutton, UK). Cells were cultured in Dulbecco's Modified Eagle's Medium (DMEM)/HAM F10 (1:1) (Gibco, Life Technology) supplemented with 50 units $/ \mathrm{ml}$ penicillin, 50 $\mu \mathrm{g} / \mathrm{ml}$ streptomycin and $10 \%$ fetal calf serum (FCS) in a humidifier incubator at $37^{\circ} \mathrm{C}$ with $5 \% \mathrm{CO}_{2}$. Oligonucleotides were delivered to the cells using Lipofectamine ${ }^{\circledR} 2000$ transfection reagent (Life Technologies, Grand Island, $\mathrm{NY}$, USA) in a final concentration of $50 \mathrm{nM}$ for a total of 24 hours. Cells were transfected with mimic pre-miRNA (Applied Biosystems, Carlsbad, CA, USA) for miR-519d$3 p$ and/or miR-4758-3p. Cells treated with lipofectamine without mimic were used as a control. Cells were washed twice with PBS before harvesting.

\section{Cell-cycle analysis}

At 24 hours after transfection, cells were collected and fixed in $90 \%$ ethanol at $4^{\circ} \mathrm{C}$ for another 24 hours. Fixed cells were then washed twice with PBS, resuspended in $200 \mu \mathrm{l}$ PBS containing $1 \mathrm{mg} / \mathrm{ml}$ propidium iodide and 1 $\mathrm{g} / \mathrm{ml}$ RNase and incubated for $10 \mathrm{~min}$ at $37^{\circ} \mathrm{C}$. Cell cycle analysis was performed using the Fluorescent-Activated Cell Sorter Canto II (BD FACSCanto II, BD Biosciences, San Jose, CA, USA).

\section{Statistical analysis}

Statistical analyses were performed with Graphpad Prism $^{\circledR}$ software (Graphpad software Inc., La Jolla, CA, 
USA). Continuous variables were described with mean and ranges; categorical variables with proportions and percentages. The non-parametric Mann-Whitney test was used to assess differences between two groups. For multiple groups, the non-parametric Kruskal-Wallis test was used followed by a Mann-Whitney test to assess differences between groups. The spearman's rank correlation test was used to assess the correlation between miR-519d-3p and miR-4758-3p. Group differences and correlations were considered significant if $\mathrm{p}<0.05$.

\section{Abbreviations}

AII: diffuse astrocytoma WHO grade II; AIII: diffuse astrocytoma WHO grade III; AP: alkaline phosphatase; AUC: area under the curve; DIG: double digoxygenin; DNTs: dysembryoplastic neuroepithelial tumours; FFPE: formalin-fixed paraffin-embedded; FCS: fetal calf serum; GB: glioblastoma; GGs: gangliogliomas; GNTs: glioneuronal tumours; HE: hematoxylin and eosin; ISH: in situ hybridization; LEATs: low-grade epilepsy-associated brain tumours; MAPK/ERK: mitogen-activated protein kinase/extracellular signalregulated kinase; miRNAs: microRNAs; MVNT: multinodular and vacuolating neuronal tumours; NGS: next generation sequencing; PA: pilocytic astrocytomas; PI3K/AKT/mTOR: phosphoinositide 3-kinase/Protein Kinase B/mechanistic target of rapamycin; PLNTY: polymorphous low-grade neuroepithelial tumours; PXA: pleomorphic xanthoastrocytoma; ROC: receiver operating characteristic.

\section{Author contributions}

EA conceived the study and participated in its design and coordination together with AI, AM and EV. FJ, WS, MT, RC, IB, KK, SJ, WG, FS, JP, AM and EA contributed to the collection and selection of tissue samples and/or clinical data. $\mathrm{AB}$ and $\mathrm{AP}$ conducted and analysed most of the experiments, supported by AA, JA and RR. AB, AP, JM, EA, AS, AM and EV wrote the manuscript. All authors read and approved the final manuscript.

\section{ACKNOWLEDGMENTS}

We are grateful to Dr Chris Jones (Institute of Cancer Research, Sutton, UK) for providing the human pediatric low grade astrocytoma cell line (WHO grade II: Res-259).

\section{CONFLICTS OF INTEREST}

None of the authors has any conflict of interest to disclose. We confirm that we have read the Journal's position on issues involved in ethical publication and affirm that this report is consistent with those guidelines.

\section{FUNDING}

This work was supported by KIKA (Stichting Kinderen Kankervrij; AB, AP, EA); Stichting AMC Foundation (EA, EV); Stichting Knip Fonds and TSC Fonds (EA); the Austrian Science Fund (FWF, no. J3499; $\mathrm{AM})$; the European Union 7th framework program: acronym EPISTOP (grant agreement no. 602391; FJ, SJ, AM, EA); the European Union 7th framework program: acronym DESIRE (grant agreement no. 602531; IB); the Polish Ministerial funds for science (years 2013-2018) for the implementation of international co-financed project (KK, SJ) and internal research project of the Children's Memorial Health Institute no.S132/2013 (KK, SJ).

\section{REFERENCES}

1. Blumcke I, Aronica E, Becker A, Capper D, Coras R, Honavar M, Jacques TS, Kobow K, Miyata H, Muhlebner A, Pimentel J, Soylemezoglu F, Thom M. Low-grade epilepsy-associated neuroepithelial tumours - the 2016 WHO classification. Nat Rev Neurol. 2016; 12: 732-40. https://doi.org/10.1038/nrneurol.2016.173.

2. Blumcke I, Aronica E, Urbach H, Alexopoulos A, GonzalezMartinez JA. A neuropathology-based approach to epilepsy surgery in brain tumors and proposal for a new terminology use for long-term epilepsy-associated brain tumors. Acta Neuropathol. 2014; 128: 39-54. https://doi.org/10.1007/ s00401-014-1288-9.

3. Thom M, Blumcke I, Aronica E. Long-term epilepsyassociated tumors. Brain Pathol. 2012; 22: 350-79. https:// doi.org/10.1111/j.1750-3639.2012.00582.x.

4. Blumcke I, Spreafico R, Haaker G, Coras R, Kobow K, Bien CG, Pfafflin M, Elger C, Widman G, Schramm J, Becker A, Braun KP, Leijten F, et al. Histopathological Findings in Brain Tissue Obtained during Epilepsy Surgery. N Engl J Med. 2017; 377: 1648-56. https://doi.org/10.1056/ NEJMoa1703784.

5. Luyken C, Blumcke I, Fimmers R, Urbach H, Elger CE, Wiestler OD, Schramm J. The spectrum of long-term epilepsy-associated tumors: long-term seizure and tumor outcome and neurosurgical aspects. Epilepsia. 2003; 44: 822-30.

6. Faramand AM, Barnes N, Harrison S, Gunny R, Jacques T, Tahir MZ, Varadkar SM, Cross HJ, Harkness W, Tisdall MM. Seizure and cognitive outcomes after resection of glioneuronal tumors in children. Epilepsia. 2018; 59: 1708. https://doi.org/10.1111/epi.13961.

7. Louis DN, Perry A, Reifenberger G, von Deimling A, Figarella-Branger D, Cavenee WK, Ohgaki H, Wiestler OD, Kleihues P, Ellison DW. The 2016 World Health Organization Classification of Tumors of the Central Nervous System: a summary. Acta Neuropathol. 2016; 131: 803-20. https://doi.org/10.1007/s00401-016-1545-1. 
8. Schindler G, Capper D, Meyer J, Janzarik W, Omran H, Herold-Mende C, Schmieder K, Wesseling P, Mawrin C, Hasselblatt M, Louis DN, Korshunov A, Pfister S, et al. Analysis of BRAF V600E mutation in 1,320 nervous system tumors reveals high mutation frequencies in pleomorphic xanthoastrocytoma, ganglioglioma and extracerebellar pilocytic astrocytoma. Acta Neuropathol. 2011; 121: 397-405. https://doi.org/10.1007/s00401-011-0802-6.

9. Rivera B, Gayden T, Carrot-Zhang J, Nadaf J, Boshari T, Faury D, Zeinieh M, Blanc R, Burk DL, Fahiminiya S, Bareke E, Schuller U, Monoranu CM, et al. Germline and somatic FGFR1 abnormalities in dysembryoplastic neuroepithelial tumors. Acta Neuropathol. 2016; 131: 84763. https://doi.org/10.1007/s00401-016-1549-x.

10. Aronica E, Crino PB. Epilepsy related to developmental tumors and malformations of cortical development. Neurotherapeutics. 2014; 11: 251-68. https://doi.org/10.1007/ s13311-013-0251-0.

11. Boer K, Troost D, Timmermans W, van Rijen PC, Spliet WG, Aronica E. Pi3K-mTOR signaling and AMOG expression in epilepsy-associated glioneuronal tumors. Brain Pathol. 2010; 20: 234-44. https://doi.org/10.1111/j.1750-3639.2009.00268.x.

12. Koelsche C, Wohrer A, Jeibmann A, Schittenhelm J, Schindler G, Preusser M, Lasitschka F, von Deimling A, Capper D. Mutant BRAF V600E protein in ganglioglioma is predominantly expressed by neuronal tumor cells. Acta Neuropathol. 2013; 125: 891-900. https://doi.org/10.1007/ s00401-013-1100-2.

13. Prabowo AS, Iyer AM, Veersema TJ, Anink JJ, Schoutenvan Meeteren AY, Spliet WG, van Rijen PC, Ferrier $\mathrm{CH}$, Capper D, Thom M, Aronica E. BRAF V600E mutation is associated with mTOR signaling activation in glioneuronal tumors. Brain Pathol. 2014; 24: 52-66. https://doi. org/10.1111/bpa.12081.

14. Dahiya S, Haydon DH, Alvarado D, Gurnett CA, Gutmann DH, Leonard JR. BRAF(V600E) mutation is a negative prognosticator in pediatric ganglioglioma. Acta Neuropathol. 2013; 125: 901-10. https://doi.org/10.1007/ s00401-013-1120-y.

15. Lee D, Cho YH, Kang SY, Yoon N, Sung CO, Suh YL. BRAF V600E mutations are frequent in dysembryoplastic neuroepithelial tumors and subependymal giant cell astrocytomas. J Surg Oncol. 2015; 111: 359-64. https://doi. org/10.1002/jso.23822.

16. Chappe C, Padovani L, Scavarda D, Forest F, NanniMetellus I, Loundou A, Mercurio S, Fina F, Lena G, Colin C, Figarella-Branger D. Dysembryoplastic neuroepithelial tumors share with pleomorphic xanthoastrocytomas and gangliogliomas BRAF(V600E) mutation and expression. Brain Pathol. 2013; 23: 574-83. https://doi.org/10.1111/ bpa. 12048.

17. Huse JT, Snuderl M, Jones DT, Brathwaite CD, Altman N, Lavi E, Saffery R, Sexton-Oates A, Blumcke I, Capper D, Karajannis MA, Benayed R, Chavez L, et al. Polymorphous low-grade neuroepithelial tumor of the young (PLNTY): an epileptogenic neoplasm with oligodendrogliomalike components, aberrant CD34 expression, and genetic alterations involving the MAP kinase pathway. Acta Neuropathol. 2017; 133: 417-29. https://doi.org/10.1007/ s00401-016-1639-9.

18. Thom M, Liu J, Bongaarts A, Reinten RJ, Paradiso B, Jager HR, Reeves C, Somani A, An S, Marsdon D, McEvoy A, Miserocchi A, Thorne L, et al. Multinodular and vacuolating neuronal tumors in epilepsy: dysplasia or neoplasia? Brain Pathol. 2018; 28:155-171. https://doi. org/10.1111/bpa.12555.

19. Qaddoumi I, Orisme W, Wen J, Santiago T, Gupta K, Dalton JD, Tang B, Haupfear K, Punchihewa C, Easton J, Mulder $\mathrm{H}$, Boggs K, Shao Y, et al. Genetic alterations in uncommon low-grade neuroepithelial tumors: BRAF, FGFR1, and MYB mutations occur at high frequency and align with morphology. Acta Neuropathol. 2016; 131: 833-45. https:// doi.org/10.1007/s00401-016-1539-z.

20. Pfister S, Janzarik WG, Remke M, Ernst A, Werft W, Becker N, Toedt G, Wittmann A, Kratz C, Olbrich H, Ahmadi R, Thieme B, Joos S, et al. BRAF gene duplication constitutes a mechanism of MAPK pathway activation in low-grade astrocytomas. J Clin Invest. 2008; 118: 1739-49. https://doi.org/10.1172/JCI33656.

21. Dias-Santagata D, Lam Q, Vernovsky K, Vena N, Lennerz JK, Borger DR, Batchelor TT, Ligon KL, Iafrate AJ, Ligon AH, Louis DN, Santagata S. BRAF V600E mutations are common in pleomorphic xanthoastrocytoma: diagnostic and therapeutic implications. PLoS One. 2011; 6: e17948. https://doi.org/10.1371/journal.pone.0017948.

22. Kakkar A, Majumdar A, Kumar A, Tripathi M, Pathak P, Sharma MC, Suri V, Tandon V, Chandra SP, Sarkar C. Alterations in BRAF gene, and enhanced mTOR and MAPK signaling in dysembryoplastic neuroepithelial tumors (DNTs). Epilepsy Res. 2016; 127: 141-51. https:// doi.org/10.1016/j.eplepsyres.2016.08.028.

23. Stone TJ, Keeley A, Virasami A, Harkness W, Tisdall M, Izquierdo Delgado E, Gutteridge A, Brooks T, Kristiansen M, Chalker J, Wilkhu L, Mifsud W, Apps J, et al. Comprehensive molecular characterisation of epilepsyassociated glioneuronal tumours. Acta Neuropathol. 2018; 135: 115-29. https://doi.org/10.1007/s00401-017-1773-z.

24. Stone TJ, Rowell R, Jayasekera BAP, Cunningham MO, Jacques TS. Review: Molecular characteristics of long-term epilepsy-associated tumours (LEATs) and mechanisms for tumour-related epilepsy (TRE). Neuropathol Appl Neurobiol. 2018; 44: 56-69. https://doi.org/10.1111/nan.12459.

25. Reschke CR, Henshall DC. microRNA and Epilepsy. Adv Exp Med Biol. 2015; 888: 41-70. https://doi. org/10.1007/978-3-319-22671-2_4.

26. Short SC. Science in Focus: MicroRNA in Glioma Potential as Biomarkers and Therapeutic Targets. Clin Oncol (R Coll Radiol). 2016; 28:543-6. https://doi. org/10.1016/j.clon.2016.04.048. 
27. Cao DD, Li L, Chan WY. MicroRNAs: Key Regulators in the Central Nervous System and Their Implication in Neurological Diseases. Int J Mol Sci. 2016; 17. https://doi. org/10.3390/ijms17060842.

28. Garg N, Vijayakumar T, Bakhshinyan D, Venugopal C, Singh SK. MicroRNA Regulation of Brain Tumour Initiating Cells in Central Nervous System Tumours. Stem Cells Int. 2015; 2015: 141793. https://doi.org/10.1155/2015/141793.

29. de Biase D, Visani M, Morandi L, Marucci G, Taccioli C, Cerasoli S, Baruzzi A, Pession A, Group PS. miRNAs expression analysis in paired fresh/frozen and dissected formalin fixed and paraffin embedded glioblastoma using real-time pCR. PLoS One. 2012; 7: e35596. https://doi. org/10.1371/journal.pone.0035596.

30. Prabowo AS, van Scheppingen J, Iyer AM, Anink JJ, Spliet WG, van Rijen PC, Schouten-van Meeteren AY, Aronica E. Differential expression and clinical significance of three inflammation-related microRNAs in gangliogliomas. J Neuroinflammation. 2015; 12: 97. https://doi.org/10.1186/ s12974-015-0315-7.

31. Scott A, Ambannavar R, Jeong J, Liu ML, Cronin MT. RT-PCR-based gene expression profiling for cancer biomarker discovery from fixed, paraffin-embedded tissues. Methods Mol Biol. 2011; 724: 239-57. https://doi. org/10.1007/978-1-61779-055-3_15.

32. Deng X, Zhao Y, Wang B. miR-519d-mediated downregulation of STAT3 suppresses breast cancer progression. Oncol Rep. 2015; 34: 2188-94. https://doi. org/10.3892/or.2015.4160.

33. Ding J, Huang F, Wu G, Han T, Xu F, Weng D, Wu C, Zhang X, Yao Y, Zhu X. MiR-519d-3p suppresses invasion and migration of trophoblast cells via targeting MMP-2. PLoS One. 2015; 10: e0120321. https://doi.org/10.1371/ journal.pone.0120321.

34. Zhou JY, Zheng SR, Liu J, Shi R, Yu HL, Wei M. MiR-519d facilitates the progression and metastasis of cervical cancer through direct targeting Smad7. Cancer Cell Int. 2016; 16: 21. https://doi.org/10.1186/s12935-016-0298-1.

35. Fornari F, Milazzo M, Chieco P, Negrini M, Marasco E, Capranico G, Mantovani V, Marinello J, Sabbioni S, Callegari E, Cescon M, Ravaioli M, Croce CM, et al. In hepatocellular carcinoma miR-519d is up-regulated by p53 and DNA hypomethylation and targets CDKN1A/p21, PTEN, AKT3 and TIMP2. J Pathol. 2012; 227: 275-85. https://doi.org/10.1002/path.3995.

36. Wu S, Huang S, Ding J, Zhao Y, Liang L, Liu T, Zhan $\mathrm{R}, \mathrm{He}$ X. Multiple microRNAs modulate p21Cip1/Waf1 expression by directly targeting its $3^{\prime}$ untranslated region.
Oncogene. 2010; 29: 2302-8. https://doi.org/10.1038/ onc. 2010.34

37. Bax DA, Little SE, Gaspar N, Perryman L, Marshall L, Viana-Pereira M, Jones TA, Williams RD, Grigoriadis A, Vassal G, Workman P, Sheer D, Reis RM, et al. Molecular and phenotypic characterisation of paediatric glioma cell lines as models for preclinical drug development. PLoS One. 2009; 4: e5209. https://doi.org/10.1371/journal.pone.0005209.

38. Chang F, Lee JT, Navolanic PM, Steelman LS, Shelton JG, Blalock WL, Franklin RA, McCubrey JA. Involvement of $\mathrm{PI} 3 \mathrm{~K} / \mathrm{Akt}$ pathway in cell cycle progression, apoptosis, and neoplastic transformation: a target for cancer chemotherapy. Leukemia. 2003; 17: 590-603. https://doi.org/10.1038/ sj.leu. 2402824 .

39. Holthausen H, Blumcke I. Epilepsy-associated tumours: what epileptologists should know about neuropathology, terminology, and classification systems. Epileptic Disord. 2016; 18: 240-51. https://doi.org/10.1684/epd.2016.0851.

40. Wang LL, Guo HH, Zhan Y, Feng CL, Huang S, Han YX, Zheng WS, Jiang JD. Specific up-regulation of p21 by a small active RNA sequence suppresses human colorectal cancer growth. Oncotarget. 2017; 8: 25055-65. https://doi. org/10.18632/oncotarget.15918.

41. Bongaarts A, Giannikou K, Reinten RJ, Anink JJ, Mills JD, Jansen FE, Spliet GMW, den Dunnen WFA, Coras R, Blumcke I, Paulus W, Scholl T, Feucht M, et al. Subependymal giant cell astrocytomas in Tuberous Sclerosis Complex have consistent TSC1/TSC2 biallelic inactivation, and no BRAF mutations. Oncotarget. 2017; 8: 95516-29. https://doi.org/10.18632/oncotarget.20764.

42. Ritchie ME, Silver J, Oshlack A, Holmes M, Diyagama D, Holloway A, Smyth GK. A comparison of background correction methods for two-colour microarrays. Bioinformatics. 2007; 23: 2700-7. https://doi.org/10.1093/ bioinformatics/btm412.

43. Iyer A, Zurolo E, Prabowo A, Fluiter K, Spliet WG, van Rijen PC, Gorter JA, Aronica E. MicroRNA-146a: a key regulator of astrocyte-mediated inflammatory response. PLoS One. 2012; 7: e44789. https://doi.org/10.1371/journal. pone. 0044789 .

44. Ramakers C, Ruijter JM, Deprez RH, Moorman AF. Assumption-free analysis of quantitative real-time polymerase chain reaction (PCR) data. Neurosci Lett. 2003; 339: 62-6.

45. Ruijter JM, Ramakers C, Hoogaars WM, Karlen Y, Bakker O, van den Hoff MJ, Moorman AF. Amplification efficiency: linking baseline and bias in the analysis of quantitative PCR data. Nucleic Acids Res. 2009; 37: e45. https://doi.org/10.1093/nar/gkp045. 